Hudson's genius, and, in spite of poverty, sustained him loyally through the lean years, to the beginning of the new century when Hudson made his breakthrough.

He was helped by two important factors. The turn of the nineteenth century saw the climax of the bicycle boom. For the first time the sensitive, not too well-heeled townsman could escape into a countryside still free from the motor car. Hudson's books on Downland, the West Country and even on the birds in the London parks struck exactly the right note, with their mixture of meticulous observation, deep knowledge and a touch of mystic communication with Nature. As one enthusiast put it, "He will do for England what Thoreau did for America".

Well, perhaps he did, but in a different way. He was the doughtiest warrior in the great Battle of the Birds. His letter to the Times on "Feathered Women" became the favourite pamphlet of the Royal Society for the Protection of Birds. But he made the public aware, not only of the threat to birds, but of the dangers to the countryside as a whole. A Shepherd's Life, published in 1910, was hailed as a masterpiece. For the rest of his life, Hudson retained a special place among nature writers and set a fashion in nature books which was widely applauded and imitated. Above all, whether they realize it or not, the half a million bird-watchers in modern Britain owe Hudson a deep debt of gratitude. After all, he is the real patron saint of the RSPB.

Will Hudson bear revival? Ruth Tomalin's well-researched and wellwritten biography sent me back to turn the

\section{IMAGE \\ UNAVAILABLE FOR COPYRIGHT REASONS}

\section{W.H. Hudson, the "caged eagle".}

pages of Far A way and Long Ago. I found it compelling reading. The Purple Land, with its picture of Argentina, Brazil and Uruguay in the early days, has a contemporary relevance. 1 am not so sure about those South American romances. Will modern readers respond to their Rima-type fantasies? Whatever may be other people's judgement, I, for one, am grateful to Ruth Tomalin's excellent book for making me take another look at The Field Naturalist from La Plata.

Wynford Vaughan-Thomas is a journalist and broadcaster.

\title{
Delayed reactions in protein biosynthesis
}

\section{H.R.V. Arnstein}

Protein Biosynthesis in Eukaryotes. Edited by R. Perez-Bercoff. Pp.501. ISBN 0-30640893-7. (Plenum: 1982.) \$71.40, £37.49.

IN THESE days of shrinking library budgets it becomes increasingly pertinent to question the usefulness of publishing the proceedings of symposia, advanced courses and similar meetings. Usually highly specialized, they tend to be only of restricted and ephemeral interest, although there are of course notable exceptions such as the Cold Spring Harbor Symposia.

This volume on eukaryotic protein biosynthesis is the record of a NATO Advanced Study Institute held in September 1980 at Maratea, Italy. Since many aspects of the topics covered in the $\mathbf{1 8}$ chapters of the book are under active investigation in many laboratories, a twoyear delay in publication is simply too long, particularly as no attempt appears to have been made to update at least the literature references by means of addenda.

The book is divided into six sections: "The protein synthesizing machinery of eukaryotes"; "On the importance of being spliced"; "On selecting the right messenger"; "'Synthesis and processing of proteins"; "Inhibition of protein synthesis at selected levels"; and "Mechanism of regulation and control"'. This division is to some extent arbitrary and, moreover, there is a certain variation in the quality and significance of the various contributions; several of them deal with topics that are covered in greater depth in recent reviews elsewhere, but on the other hand very few chapters would be useful to nonspecialists.

Despite these criticisms, the book will be useful to research workers in the field as it contains a lot of interesting information. Space does not permit any detailed discussion of individual contributions, but I enjoyed particularly the articles on recognition sites in eukaryotic messenger RNAs (M. Kozak), the function of the cap in mRNA translation (A.J. Shatkin) and the cytoplasmic control of protein synthesis (R.J. Jackson). A major gap in the coverage of eukaryotic protein synthesis is the omission of any discussion of the transfer of proteins into and through membranes. The elegant signal hypothesis proposed by Blobel to account for the vectorial synthesis and release of secretory proteins is surely one of the most important developments (for a recent account see $P$. Walter and G. Blobel's article in Nature 299, 691-698). There are also other, more minor, omissions. For example, in the chapter on mRNP particles there is no mention of Greenberg's recent investigations of mRNP structure by crosslinking the proteins to the RNA by uv irradiation.

Finally, I must take issue with a state- ment in the foreword that the basic mechanism of protein synthesis was "first unravelled in bacterial systems". Those of us who are old enough to remember and young enough not to have forgotten will recall that Zamecnik's group, working with rat liver preparations, discovered the function of both microsomes (membranebound ribosomes) and soluble RNA (transfer RNA). Moreover, the first complete nucleotide sequence of a transfer RNA was that established by R.W. Holley for yeast alanine tRNA. In a book on eukaryotic protein synthesis these earlier and important discoveries deserve to be mentioned.

H.R.V. Arnstein is Head of the Biochemistry Department at King's College, University of London.

\section{More from the Moon}

\section{J.W. Head}

Planetary Science: A Lunar Perspective. By Stuart Ross Taylor. Pp.481. ISBN 0-942862-00-7. (Lunar \& Planetary Institute, Houston, Texas: 1982.) $\$ 42.95$ (US), \$54.95 (elsewhere).

TwO YEARS after Apollo 17, S. Ross Taylor published Lunar Science: A Post-Apollo View, a book designed to bring some order to our knowledge of the Moon's evolutionary history resulting from the abundance of information derived from the Apollo and Luna missions. In this book, published eight years later, Taylor has attempted to incorporate the results of the exploration of the other planetary bodies into a broader perspective on the origin and evolution of the Solar System, relying heavily on the lunar data as a basis for this new understanding.

Although he writes with an admitted bias towards geochemistry, the author treats his broad subject matter with fairness and evenness. There are excellent chapters on the exploration of the Solar System, on basic planetary processes such as impact cratering and volcanism, and on the nature of planetary crusts, interiors and the stratigraphic record of the planets. Helpful appendices on sources of data and a glossary make the book a valuable introduction to the field. In addition, reflective summaries of where we have been and where we are going capture the unique spirit of lunar and planetary exploration. A chapter on the origin and evolution of the planets provides an especially well-written summary of a very difficult topic, although the author's preference for the doubleplanet hypothesis for the origin of the 